\title{
Workshop Pemanfaatan Laboratorium Virtual IPA Sebagai Media Pembelajaran di Masa Pandemi
}

\author{
Susdarwati, Desi Nuzul Agnafia, Arifian Dimas \\ STKIP Modern Ngawi \\ susdarwati88sains@gmail.com
}

\begin{abstract}
ABSTRAK
Pembelajaran IPA tidak terlepas dari keterampilan proses sains, di mana siswa tetap harus melakukan praktikum untuk memahami atau membuktikan teori dan konsep-konsep yang ada. Salah satu Praktikum yang dapat dilakukan di masa pandemi adalah Praktikum Virtual di rumah yaitu menggunakan bantuan aplikasi komputer berbasis IT seperti virtual laboratory.Tujuan pengabdian adalah menambah wawasan dan pengetahuan pada pendidik, peserta didik, dan masyarakat pada umumnya tentang manfaat dan macam-macam Laboratorium Virtual IPA sebagai media pembelajaran di masa pandemi.Metode kegiatan adalah menyampaikam materi dalam bentuk workshop melalui metode ceramah bervariasi dan tanya jawab. Hasil pengabdian kepada masyarakat adalah: 1) keberhasilan target jumlah peserta seminar mencapai $60 \%$ yaitu 300 orang, 2) ketercapaian tujuan kegiatan secara umum telah tercapai yaitu hasil angket $86,8 \%$ kategori sangat bermanfaat sekali dalam menambah wawasan dan pengetahuan tentang Laboratorium Virtual IPA sebagai media pembelajaran di masa pandemi, dan 3) ketercapaian target materi pada kegiatan pengabdian masyarakat yaitu 91,2\% kategori sangat baik terbukti materi telah disampaikan secara keseluruhan dan adanya kesesuaian materi dengan kebutuhan.
\end{abstract}

Kata kunci : laboratorium virtual ipa, media pembelajaran, masa pandemi

\begin{abstract}
Science learning is inseparable from science process skills, where students still have to do practicum to understand or prove existing theories and concepts. One of the practicums that can be done during a pandemic is a virtual practicum at home, which is to use the help of IT-based computer applications such as virtual laboratories. Science as a medium of learning during a pandemic. The method of activity is to deliver material in the form of workshops through various lecture methods and questions and answers. The results of community service are: 1) the success of the target number of seminar participants reached $60 \%$, namely 300 people, 2) the achievement of the activity objectives in general has been achieved, namely the results of the questionnaire $86.8 \%$ category are very useful in adding insight and knowledge about the Virtual Science Laboratory as learning media during the pandemic, and 3) the achievement of material targets in community service activities, namely $91.2 \%$ very good category, it is proven that the material has been delivered as a whole and there is a conformity of the material with needs.
\end{abstract}

Keywords : virtual science laboratory, learning media, pandemic period 


\section{PENDAHULUAN}

Pada 31 Desember 2019 muncul kasus serupa dengan pneumonia yang tidak diketahui di Wuhan, China (Lee, 2020). Kasus tersebut di akibatkan oleh virus corona atau yang dikenal dengan COVID-19 (Corona Virus Desese-2019). Dampak yang ditimbulkan dari pandemi COVID-19 telah mengubah berbagai aspek kehidupan manusia khususnya pendidikan. Banyak negara memutuskan menutup sekolah maupun perguruan tinggi. Penutupan sementara lembaga pendidikan sebagai upaya menahan penyebaran pendemi covid-19 di seluruh dunia berdampak pada jutaan pelajar, termasuk Indonesia. Gangguan dalam proses belajar langsung antara siswa dan guru dan pembatalan penilaian belajar berdampak pada psikologis anak didik dan menurunnya kualitas keterampilan siswa. Beban itu merupakan tanggung jawab semua elemen pendidikan khususnya Negara dalam memfasilitasi kelangsungan sekolah bagi semua steakholders pendidikan guna melakukan pembelajaran jarak jauh. Bagaimana mestinya Indonesia merencanakan, mempersiapkan, dan mengatasi pemulihan covid 19, untuk menekan kerugian dunia pendidikan di masa mendatang.

Terdapat dua dampak bagi keberlangsungan pendidikan yang disebabkan oleh pandemi Covid-19. Pertama adalah dampak jangka pendek, yang dirasakan oleh banyak keluarga di Indonesia baik di kota maupun di desa. Wabah COVID-19 mendesak pengujian pendidikan jarak jauh hampir yang belum pernah dilakukan secara serempak sebelumnya bagi semua elemen pendidikan yakni peserta didik, guru hingga orang tua (Sun et al., 2020). Di Indonesia banyak keluarga yang merasa kesulitan melakukan sekolah di rumah khususnya bagi produktivitas orang tua yang memiliki kesibukan dengan pekerjaan di luar rumah. Demikian juga dengan problem psikologis anak-anak peserta didik yang terbiasa belajar bertatap muka langsung dengan guru-guru mereka. Seluruh elemen pendidikan secara kehidupan sosial "terpapar" sakit karena covid-19. Pelaksanaan pengajaran berlangsung dengan cara online. Proses ini berjalan pada skala yang belum pernah terukur dan teruji sebab belum pernah terjadi sebelumnya. Penilaian siswa secara online dan banyak trial and error dengan sistem yang tidak ada kepastian, malah banyak penilaian yang banyak dibatalkan. Kedua adalah dampak jangka panjang. Banyak kelompok masyarakat di Indonesia yang akan terpapar dampak jangka panjang dari covid-19 ini. Dampak pendidikan dari sisi waktu jangka panjang adalah aspek keadilan dan peningkatan ketidaksetaraan antar kelompok masyarakat dan antardaerah di Indonesia.

Guru dan pendidik sebagai elemen penting dalam pengajaran diharuskan melakukan migrasi besar-besaran yang belum pernah terjadi sebelumya dari pendidikan tatap muka tradisional ke pendidikan online atau pendidikan jarak jauh (Bao, 2020; Basilaia \& Kvavadze, 
2020). Ini didukung dengan perkembangan teknologi yang tidak terbatas pada revolusi industry 4.0 saat ini. Pembelajaran online secara efektif untuk melaksanakan pembelajaran meskipun pendidik dan peserta didik berada di tempat yang berbeda (Verawardina et al., 2020). Ini mampu menyelesaikan permasalahan keterlambatan peserta didik untuk memperoleh ilmu pengetahuan.

Proses pembelajaran di sekolah merupakan alat kebijakan publik terbaik sebagai upaya peningkatan pengetahuan dan keterampilan (Caroline Hodges Persell, 1979). Pembelajaran IPA tidak terlepas dari keterampilan proses sains, di mana siswa tetap harus melakukan praktikum untuk memahami atau membuktikan teori dan konsep-konsep yang ada. Salah satu praktikum yang dapat dilakukan di masa pandemi adalah Praktikum Virtual di rumah yaitu menggunakan bantuan aplikasi komputer berbasis IT seperti virtual laboratory.

Laboratorium virtual menggabungkan pengalaman modalitas visual dan auditory dan memerlukan siswa untuk secara aktif terlibat (Habraken, 2004). Laboratorium virtual tidak memerlukan laboratorium fisik, namun dapat menggambakan kepada siswa seolah-olah kegiatan pembelajaran ini berada di laboratorium. Robeck menyatakan bahwa kelebihan pembelajaran virtual antara lain: 1) mengaplikasikan kemahiran dalam proses sains, 2) inquiri sains, 3) pemikiran kritikal, 4) pemahaman konseptual, dan 5) pemahaman kepada sains alam (Arba'at, 2008). Siswa dilatih untuk berpikir dan melakukan percobaaan secara virtual untuk menamankan konsep-konsep. Melalui pembelajaran laboratorium virtual ini, percobaan-percobaan yang dilakukan tidak memerlukan waktu yang lama karena langsung disimulasikan hasilnya sehingga pembelajaran ini menghemat waktu.

Tujuan kegiatan pengabdian kepada masyarakat ini adalah untuk menambah wawasan dan pengetahuan pada pendidik, peserta didik, dan masyarakat pada umumnya tentang manfaat dan macam-macam Laboratorium Virtual IPA sebagai media pembelajaran di masa pandemic.

\section{BAHAN DAN METODE}

Kegiatan pengabdian masyarakat yang dilaksanakan secara online melalui akun google meet https://meet.google.com/ybjvzre-hzp. Kegiatan ini dilaksanakan dalam waktu dua kali pertemuan, yakni pada hari Sabtu-Minggu tanggal 19-20 September 2020 dari pukul 08.45-12.00 WIB. Sasaran kegiatan pengabdian masyarakat ini adalah pendidik, peserta didik, dan masyarakat pada umumnya. Peserta kegiatan berjumlah 300. Adapun yang menjadi narasumber dalam kegiatan ini adalah Susdarwati, M.Pd., Desi Nuzul Agnafia, M.Pd., dan Arifian Dimas, M.Pd. yang merupakan dosen Program Studi Pendidikan IPA STKIP Modern Ngawi serta Dr. Wirawan Fadly, M.Pd. yang merupakan dosen IAIN Ponorogo dan Dr. Agung Subiantoro, M.Pd. yang merupakan dosen Universitas Negeri Yogyakarta.

Langkah-langkah kegiatan pengabdian kepada masyarakat adalah sebagai berikut: 1) 
membuat proposal kegiatan yang diajukan kepada Ketua STKIP Modern Ngawi; 2) menetapkan jadwal dan rundown acara workshop; 3) membuat pamphlet kemudian menyebarkan via media sosial seperti Facebook, Whatshap, dan Instagram; 4) menetapkan materi yang akan diberikan dalam kegiatan tersebut; dan 5) menyampaikan materi dalam bentuk workshop menggunakan metode ceramah bervariasi dan tanya jawab.

\section{HASIL}

Kegiatan pengabdian masyarakat yang dilaksanakan secara online melalui akun google meet dalam bentuk workshop ini berjalan dengan baik dan lancar. Pelaksanaan kegiatan pengabdian masyarakat ini terbagi menjadi beberapa materi, adapaun materinya adalah: 1) Makna dan manfaat Laboratorium virtual IPA sebagai media pembelajaran di masa Pandemic dan 2) Contoh dan simulasi penggunaan Laboratorium virtual IPA.

Kegiatan yang diawali dengan pembukaan oleh moderator. Wakil Ketua I STKIP Modern Ngawi membuka acara. Moderator memandu acara inti. Moderator meyampaikan Curiculum Vitae dilanjutkan narasumber menyampaikan materi. Narasumber memberikan materi pada peserta tentang manfaat Laboratorium virtual IPA sebagai media pembelajaran di masa Pandemic.

Setelah itu, sesi tanya jawab memberikan kesempatan tanya jawab pada peserta terkait hal-hal yang masih belum dipahami. Berbagai pertanyaan diajukan secara antusias oleh peserta dalam sesi tanya jawab. Secara garis besar inti dari pertanyaan peserta adalah seberapa efektifitas laboratorium virtual IPA ini untuk meningkatkan keterampilan pada siswa.

Setelah sesi Tanya jawab, kemudian operator membagikan link daftar hadir kepada peserta sebagai salah satu syarat untuk mendapatkan sertifikat. Setelah itu, acara seminar ditutup dengan doa.

Program pengabdian masyarakat berupa workshop ini diharapkan dapat menambah pengetahuan, wawasan, serta pemahaman para praktisi pendidikan dalam menggunakan media pembelajaran laboratorium virtual IPA. Diharapkan praktisi pendidikan dapat memanfaatkan laboratorium virtual untuk mengembangkan aspek keterampilan meski pembelajaran dilakukan secara online.

\section{PEMBAHASAN}

Hasil pelaksanaan kegiatan pengabdian masyarakat ini secara garis besar mencakup beberapa komponen, yaitu:

1. Keberhasilan target jumlah peserta seminar

Target peserta workshop seperti yang direncanakan sebelumnya adalah 500 peserta. Dalam pelaksanaannya, kegiatan ini dihadiri oleh 300 orang. Dengan demikian dapat dikatakan bahwa jumlah peserta mencapai $60 \%$. Angka tersebut menunjukkan bahwa kegiatan pengabdian masyarakat ini apabila dilihat dari jumlah peserta yang mengikuti dapat 
dikatakan cukup berhasil karena lebih dari $50 \%$. Penyebaran pamflet dilakukan mulai tanggal 8 September 2020 dan acara dilaksanakan pada tanggal 19-20 September 2020. Hal ini disimpulkan bahwa hanya 11 hari untuk penyebaran pamflet tersebut sehingga sebagai evaluasi untuk acara webinar dan workshop selanjutnya sebaiknya untuk penyebaran pamflet minimal 30 hari.

2. Ketercapaian tujuan kegiatan

Ketercapaian tujuan kegiatan secara umum telah tercapai. Hasil feedback dari peserta terkait nilai manfaat yang dirasakan peserta kegiatan sebanyak $86,8 \%$ merasa sangat bermanfaat sekali, $8,2 \%$ merasa sangat bermanfaat dan $5 \%$ merasa cukup bermanfaat. Hal ini membuktikan bahwa wawasan serta pengetahuan peserta tentang manfaat dan penggunaan laboratorium virtual IPA sebagai media pembelajaran di masa Pandemi mengalami peningkatan.

3. Ketercapaian target materi yang telah direncanakan.

Ketercapaian target materi pada kegiatan pengabdian masyarakat ini cukup baik. Hal ini dikarenakan adanya kesesuaian materi dengan kebutuhan peserta serta materi telah disampaikan secara keseluruhan.

Jadi secara keseluruhan kegiatan pengabdian masyarakat ini dapat dikatakan berhasil. Keberhasilan ini selain diukur dari tiga komponen di atas, juga dapat dilihat dari kepuasan peserta setelah mengikuti kegiatan
93,3\% mengumpulkan produk webinar dan workshop. Manfaat yang diperoleh peserta adalah dapat menambah semangat dan motivasi untuk tetap melakukan praktikum guna mengembangkan keterampilan siswa walaupun pembelajaran dilaksanakan secara online.

\section{KESIMPULAN DAN SARAN}

Pelaksanaan program pengabdian masyarakat dalam bentuk Workshop "Pemanfaatan Laboratorium Virtual IPA Sebagai Media Pembelajaran di Masa Pandemi" ini dapat diselenggarakan dengan baik dan berjalan lancar. Hal ini dibuktikan bahwa:1) Kegiatan ini mendapat sambutan sangat baik terbukti dari keaktifan peserta mengikuti seminar. Hampir semua peserta antusias dan merasakan manfaat pelatihan; dan 2) Adanya respon yang positif dari peserta karena kegiatan ini merupakan kebutuhan praktisi pendidikan dalam rangka mengatasi kesulitan pemilihan media pembelajaran IPA yang tetap mengutamakan aspek keterampilan walaupun pembelajaran secara online.

Berdasarkan evaluasi yang telah dilakukan dapat diajukan beberapa saran yaitu: 1) Penyebaran pamflet webinar dan workshop dilakukan minimal 30 hari sebelum hari $\mathrm{H}$ pelaksanaan guna mendapat peserta yang maksimal sesuai dengan target. 2) Waktu pelaksanaan simulasi praktikum laboratorium virtual IPA sebaiknya ditambah agar peserta bisa maksimal mempraktikannya. 


\section{UCAPAN TERIMA KASIH}

Terimakasih kepada STKIP Modern Ngawi, IAIN Ponorogo, dan Universitas Negeri Yogyakarta yang sudah mendukung dan partisipasi sebagai realisasi MoU di bidang Pengabdian kepada Masyarakat, sehingga kegiatan dalam bentuk workshop ini dapat terselenggara dengan baik.

\section{DAFTAR PUSTAKA}

Arba'at. 2008. Pembelajaran virtual. Yogyakarta: PustakaPelajar.
Bao, W. 2020. COVID-19 and online teaching in higher education: A case study of Peking University. March, 113-115.

Lee, A. 2020. Wuhan novel coronavirus (COVID-19): why global control is challenging? Public Health, January, 19-21.

Sun, L., Tang, Y., \& Zuo, W. 2020. Coron avirus pushes education online.

Verawardina, U., Asnur, L., Lubis, A. L., \& Hendriyani, Y. 2020. Reviewing Online Learning Facing the Covid19 Outbreak. 12(3), 385-392.

\section{LAMPIRAN}

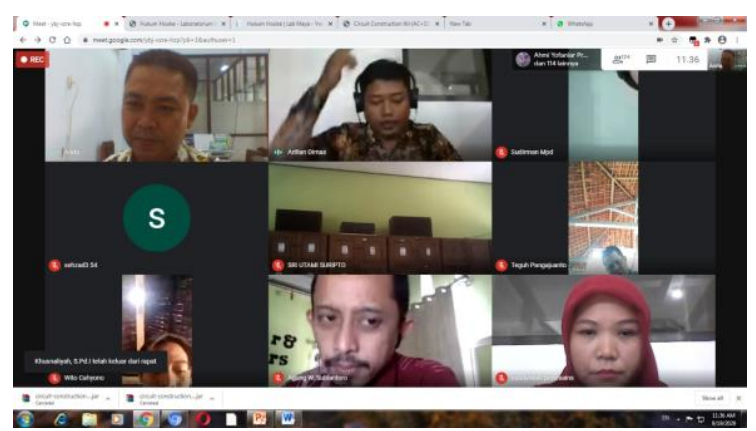

Gambar 1. Penyampaian Materi

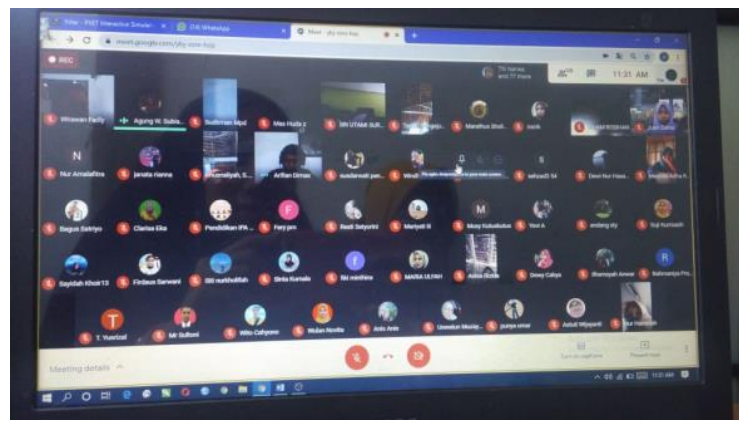

Gambar 2. Sesi Tanya Jawab 